\title{
AN EXPLORATION OF GRAFFITI ON UNIVERSITY'S WALLS A CORPUS-BASED DISCOURSE ANALYSIS STUDY
}

\author{
Nisreen Naji Al-Khawaldeh' \\ Imad Khawaldeh² \\ Baker Bani-Khair ${ }^{3}$ \\ Amal Al-Khawaldeh ${ }^{4}$ \\ Department of English Language and Literature - The Hashemite University, Jordan 1, 2, 3 \\ University of Jordan ${ }^{4}$ \\ nal-khawaldeh@hu.edu.jo', imad32II@yahoo.com², bakribakr@yahoo.com³, a_khawaldeh@ju.edu.jo
}

First received: 22 January 2017

Final proof received: 30 May 2017

\begin{abstract}
Graffiti have received a great attention from scholars as they have been considered a vital cultural phenomenon for many years (Trahan, 2011; Divsalar \& Nemati, 2012; Zakareviciute, 2014; Farnia, 2014; El-Nashar \& Nayef; 2016). Although there are extensive contemporary researches on graffiti in many disciplines, such as linguistics, cultural studies, politics, art, and communication (Pietrosanti, 2010; Farnia, 2014; Oganda, 2015), there are few studies exploring graffiti on classrooms' walls in higher education milieus (Farnia, 2014). To the best knowledge of the researchers, very few studies were done on the Jordanian context (e.g. Al-Haj Eid, 2008; Abu-Jaber, et al., 2012) and none was done on the Jordanian universities. Therefore, this study aims at analysing the content and communicative features of writings found on universities' classrooms' walls, corridors, and washrooms and their relation to the socio-cultural values of the society in order to explore how universities help students voice their attitudes and thoughts. The linguistic features that characterise these writings were also examined. Graffiti-writings, which were collected from the University of Jordan and the Hashemite University, were coded and analysed using the thematic content analysis technique (Braun \& Clarke, 2006) and Critical Discourse Analysis (Fairclough, 1995). The analysis of the data has shown that graffiti serve different communicative language functions related to personal, social, national, religious, political, and taboo matters. The most salient linguistic features of these graffiti are simplicity and variation. It can be concluded that graffiti are distinctive and silent ways of communication, particularly in students' society. The study will be of great importance to linguists, sociologists, educators, administrators, teachers and parents. It is enrichment to the available literature on linguistic studies.
\end{abstract}

Keywords: Critical Discourse Analysis; graffiti; socio-cultural values; sociolinguistics; corpora

Graffiti have been viewed as a significant cultural phenomenon over a long period of time (Ferrell, 1996; Rawlinson \& Farrell, 2010; Trahan, 2011; Blommaert, 2016). Despite their significance, they are also abhorrent, being perceived as an undesirable annoyance and a mere illegal act of vandalism and mischief that contributes to a general sense of a heightened fear of crime and results in destruction to public or private property (Agnes, et al., 2014; DeNotto, 2014; El-Nashar \& Nayef, 2016; Karlander, 2016; Vanderveen \& Eijk, 2016). However, people still continue to write on walls in spite of the fact that the digital world (e.g. twitter, Facebook) offers an avenue for them to express their opinions freely (Matthews et al., 2012). This phenomenon is visible on almost every possible surface in Jordanian schools, parks, universities, and public restrooms. Farnia (2014) explained what motivates and drives people to put down such inscriptions on the walls they pass by. She claims that graffiti are people's channels through which they represent their voice in either public or secluded places to express their annoyance, prompt thoughts, affection, personal announcement, political declaration, or even their outcry. This implies that they can be regarded as a second diary book (Raymonda, 2008) that reveals significant information to those interested in the exploration of the society's concerning issues, discipline and order, or personal ego-starved or concerned mind (Reisner \& Wechsler, 1974). Graffiti have also been viewed by scholars as a "freedom of expression" as people are kept anonymous (Tracy, 2005, p. 22). People generally cannot spontaneously voice their personal expressions due to being controlled by personal and social norms (Abel \& Buckley, 1977).

In the following sections, the statement of the problem and the significance of the study are clarified. Besides, the previous researches are critically reviewed and the research methodology is discussed. The results of the study are presented and discussed and a conclusion of the study is provided.

\section{Statement of the Problem}

Though graffiti are largely regarded as an illegal action that results in destruction to public or private 
property, they have been viewed by many others as an artistic technique (Stampoulidis, 2016). There has been a growing interest amongst researchers in the "linguistic landscape" (Blommaert, 2012) which encompasses a wide variety of forms and modes of language use and endeavours to comprehend the intentions, usages, ideologies, language variations of several forms of languages, particularly written signs displayed in public spaces (Shohamy \& Barni, 2010).

Graffiti have received a great attention from scholars as they have been considered a vital cultural phenomenon for many years (Trahan, 2011; Divsalar \& Nemati, 2012; Zakareviciute, 2014; Farnia, 2014; El-Nashar \& Nayef, 2016). Culture according to Hofstede (2005) is the discernible practices of the society. The significance of graffiti also stems from the fact that they have been considered as a profound source that encompasses insightful psychological, societal, and cultural information worthy of thoughtful attention (Farnia, 2014; El-Nashar \&Nayef, 2016). Researchers (Farnia, 2014; El-Nashar \& Nayef, 2016) argued that such statements are a very great mode of expression for groups that in essence feel deprived and marginalized by the wider strata of society. Those groups who are forbidden from or deprived of avenues of public expression pursue other easy channels, such as graffiti on public places' walls. With respect to scope of the study, the present researchers as others (e.g. Farnia, 2014; Kariuki, et al., 2016) observe that student population in most parts of the world is perceived as being deprived of enjoying the privilege of public self-expression. This could be referred to the fact that the adolescents are largely misinterpreted in the dominantly adult-run society which decrees social structure that results in a distance between the adolescents and the adults and leads the adolescents to act out against the authoritative society that constrains them. Therefore, they prefer graffiti as a channel through which they air their attitudes, beliefs, worries, interests, and feelings concerning their world and surroundings. Considering this and the fact that graffiti offer them such a forum with privacy and anonymity means that they avail the chance fully and safely to express themselves without fright of any probable consequences. Accordingly, graffiti should be investigated, being viewed as a depiction of the existing issues among students. That is why researchers (e.g. Yieke, 2003; Al-Haj Eid, 2008; Farnia, 2014) call for more studies to be conducted on graffiti, suggesting that graffiti should never be overlooked by those in authority if they need to know the sentimentalities and desires of the students.

Graffiti could also be viewed as a platform for immemorial and social communication in innumerable societies (Mirzaalikhani, 2011; Gröndahl, 2012; Bunting, 2012; Szpila, 2012; Farnia
\& Tohidian, 2013; Farnia, 2014; Lennon, 2014; Sheivandi et al., 2015; Peiris \& Jayantha, 2015; Kariuki, et al., 2016). Therefore, analysing graffiti could offer vital information for the examinations of the social and personal concerning issues, such as discipline or ego-starved or worried mind (Reisner $\&$ Wechsler, 1974). Besides, they can also be regarded a good source of data for enriching linguistic studies focused on analysing discourse patterns, investigating various cultural production, and examining gender-based language differences (Farnia, 2014). Not only regarded as a source of current vital information, but graffiti are also perceived as a pointer to the future actions or intensions (Zakareviciute, 2014).

Although there are extensive contemporary researches on graffiti in many disciplines, such as psychology, linguistics, cultural studies, history, politics, art, and communication (Pietrosanti, 2010, Farnia, 2014, Oganda, 2015), there are few studies exploring graffiti on classrooms' walls in higher education milieus (Farnia, 2014). This implies that there is still room to examine how graffiti in different contexts serve to voice their people's opinions and bring out the issues that influence them. To the best knowledge of the researchers, very few studies were done on the Jordanian context (e.g. Al-Haj Eid, 2008, Abu-Jaber, et al., 2012) and none was done on the Jordanian universities. This study bridges the research gap, as it tackles the university classrooms' walls and washrooms in particular due to the independence, anonymity, and freedom of expression they offer the graffitists. The researchers were motivated to conduct this study due to their observation that universities, schools, colleges, and lodges seem to be the centre of institutional graffiti and McGlynn's (1972) finding that the anonymity results in accurate and unrestricted expression of sentiment as it enables the graffitists the opportunity to use the type of language that better expresses their opinions and attitudes even if they are taboo in ordinary social life. The idea of this study was also triggered by AlHaj Eid's (2008) recommendation that further studies should be conducted on thematic and linguistic features of graffiti in Jordan in general and in Jordanian higher educational institutions in particular.

\section{Significance of the Study}

This study draws its significance from the fact that it is a source of enrichment to the available literature on linguistic studies concerned with corpus analysis, psycholinguistics, discourse analysis, and sociolinguistics, investigating various social and cultural productions of graffiti language differences. The findings of the study can contribute to the body of research in discourse studies and sociolinguistics by providing a valuable analysis of language use in society and its importance in revealing great 
information about the psychology of the graffitists. The study will be of a great value to those interested in studying political, religious, social and personal, psychological issues. Besides, it is an exploration of some of the linguistic features that help reveal the values and cultural norms of the Jordanian society, since through these writings, the graffitist generates and regenerates ideologies and beliefs (van Dijk, 1999).With respect to the scope of the study and as Al-Haj Eid (2008) claimed, students' graffitiwritings can be viewed as a worthy index of their socio-economic background as well as a very influential mode of expression in a wide range of topics, particularly for those who feel disenfranchised by the society (Farnia, 2014). In light of Al-Khawaldeh's (2014) assertion that any linguistic feature in a community shows variation that differs in frequency from one social group to another in a patterned and expectable way, it is hoped that this study would offer a valuable source of data for those in authority. It would help in revealing students' feelings, opinions, and attitudes as well as showing how graffiti significantly contribute to education, as they encourage students to write freely and think critically. Graffiti are students' ways of articulating genuine concerns and problems that they would never openly discuss with the authority and if appropriately addressed would be beneficial to the smooth running of educational institutions. The Ministry of Higher Education and Education Stakeholders may find the findings of the present study useful in identifying and stemming impending strikes in learning institutions, particularly in Jordan. In addition, it will help university presidents and professors in understanding students' community in an attempt to construct a conducive and peaceful learning environment and ultimately improve performance.

\section{Literature Review}

The concept of "graffiti" is derived originally from the Italian word "graffito" which is mainly employed to refer to "any form of writing or images on the walls or surfaces of public buildings, parks, toilets, buses or trains, usually bearing some political or sexual contents, a lover's pledge, proposition, or obscene words" (Chiluwa, 2008, p. 274). Blume (1987) defined graffiti as any graphic or written inscriptions for which no official establishment is made, which are largely undesirable, and which are written on the most several publicly reachable surfaces, typically by anonymous people. Graffiti have been considered as a map of a genuine representation of reality as well as an evolutionary means that has made people reflect on their cultural identity using artistic and social modes of expressions (Sheivandi et al., 2015). Abel and Buckley (1977, p. 3) view it as:

A form of communication that is both personal and free of the everyday social strains that normally prevent people from giving uninhibited reign to their thoughts. As such, these sometimes crude inscriptions offer some intriguing insights into the people who author them and into the society in which these people belong.

Basthomi (2007) argued that graffiti are related to any sort of symbols, scratches, drawings, signs, paintings found on walls or anywhere irrespective to what inspires the writing. Considering their various forms, they have been studied from different angles: social (Adams \&Winter, 1997), cultural, religious (Chiluwa, 2008), political (Salamon, 2005, Morva, 2016), language learning (Mwangi, 2012), motivational and emotional (Peiris, and Jayantha, 2015), gendered (House, 2007, Matthews, et al., 2012, Haslem, 2012), linguistics (Grider, 1975, Abu-Jaber, et al., 2012) quantitative, preventative, and aesthetic (for more illustration see Gadsby, 1995).

Attitudes towards graffiti are ambivalent. Graffiti have been seen as an undesirable annoyance, a sign of rebellion against societal authorities, and an utter manifestation of destruction that must be mended (Nwoye, 1993). On the other hand, they are regarded as an unconventional medium or an alternative form of personal communication that is free of ordinary social limitations that avert people from freely flow their thoughts (Abel \& Buckley (1997) and a source of information about significant social issues and problems (Yieke, 2003). Hence, Gross et al. (1997) argued that graffiti are human products and forms of communication which can be inferred, examined, and understood.

Despite their manifestations, graffiti are viewed as a linguistic phenomenon that encompasses both form and content and uses discourse to signify something other than itself (Mwangi 2012). Considering their various contents, researchers have come up with different classifications. For example, Dombrowski (2011) has classified graffiti found in four universities' libraries in the United States into the following themes: advice, classes, despair, and drugs, where those graffiti concerning the theme of insults and remarks about the previously-mentioned themes were the most distinctive themes of graffiti besides sex. Şad and Kutlu (2009) classified graffiti into socially acceptable themes, such as belongingness, homesickness, romance, and humour or the form of someone's name and signs (doodling) and anonymous inscriptions themes, such as sex and politics or religion, which are found to be the production of men rather than women.

Graffiti have also been classified as either latrinalia, humorous, public, tags, folk epigraphy, or historical (Gadsby, 1995). In particular, latrinalia, which is termed by Dundes (1966), refers to restrooms' graffiti. As claimed by Haslam (2012, p. 15) public toilets are "ideal hothouses and are 
associated with activities that make taboo ideas and images highlight salient". This can be explained by the fact that public washrooms offer graffitists almost a complete anonymity which enables them to freely use specific types of language and express sentiments and outlooks that cannot be overtly expressed as they may be considered taboo in everyday social life. That is why, McGlynn (1972) argued that anonymous graffiti are an exceptionally precise and unobstructed manifestation of sentimentality. With regards to humorous graffiti, Gadsby (1995) viewed graffiti as a sort of writing that is purposefully produced in order to invoke entertainment. Some researchers (e.g. Beck, 1982; Warakomski, 1991) examined this type of graffiti linguistically in order to find out what motivated their writers. Public graffiti, on the other hand, include graffiti written on public spaces and sites (i.e. walls of building, trains, or buses). Tags are unique representation of individuals and they often employ writers' specific characteristics, such as names, initials, addresses, etc. As Reisner (1974, p. 4) pointed out, "As the graffiti writer gets more and more into these open areas where his chances of being seen are greater, there is a tendency for his message to be of a generalized nature without too much pornographic emphasis....in lavatories, or in any place where there is complete privacy, however, the messages, although still often banal, are much more visceral". Investigating graffiti done by political groups, Pietrosanti (2010) found the main themes revolved around civil rights, freedom, unemployment, labour conditions, political power, and religious thought. Examining graffiti inscribed by school students, Mwangi (2012) found that students varied communicative functions like humour, symbolism, irony, short forms, acronyms, and abbreviations in their graffiti writings.

Linguistically analysing graffiti, Al-Haj Eid (2008) revealed that simplicity is a noticeable linguistic feature of school students' graffitiwritings. He asserted that simple sentences are used as they are not time-consuming and statements are used due to their informative nature. Alliteration and rhyming are also found to be used by the graffitists as attention-getting devices. Sheivandi et al. (2015) revealed linguistic peculiarities of graffiti, such as alteration of consonant which results in opposing the meaning of sentence, alteration of already existing expressions, such as proverbs, the use of parallel syntax, the use of conditional patterns and punning on re-division of words in the use of dialogues.

It is worth noting that many of the studies investigating graffiti use thematic analysis and Critical Discourse Analysis. Building on the methodology used in the foregoing related studies for analysing the data (Rawlinson \& Farrell, 2010; El-Nashar, \& Nayef, 2016; Morva, 2016; Stampoulidis, 2016; Yeo, et al., 2016) and that specifically serves the objectives of the present study, thematic analysis and Critical Discourse Analysis are considered as the main tools for quantitative and qualitative clarification. This is because graffiti have proved to be a medium people use to respond to socio-political issues influencing their lives. The thematic analysis helps the researcher to classify the "raw" data into meaningful concepts and then group them into relevant allencompassing categories in order to examine the main prevalent themes and the contextual meanings of students' graffiti. Critical Discourse Analysis is also needed, as it is based on the interaction between the graffiti text, discursive practices, and the social context (Fairclough, 2003). Graffiti are types of discourse that should be understood in the context of power relations because power is essential to the creation and sustenance of knowledge in society. They clarify, express, and shape the properties of the socio-cultural situation. Consequently, it is valuable and crucial to recognize and examine the importance of graffiti as a product of human linguistic expression besides the nature and impact of the message being conveyed (Onyango, 2016).

\section{METHOD \\ Research Aims and Questions}

The study endeavours to investigate the functions that graffiti-writings serve (i.e. the thematic content of the statements), and the distinctive lexical and syntactic features that characterize the language of graffiti-writings on the university walls. In light of these aims, the study attempts to answer the following questions: (1) What communicative functions do graffiti-writings serve? And (2) What are the distinctive lexical and syntactic features that characterize the language of graffiti-writings?

\section{Data Collection}

This is a corpus-based discourse analysis study. Discourses are drawn from messages written on university's walls, particularly classrooms', corridors', and toilets' walls. The randomly selected sample consists of graffiti found in two universities, namely The University of Jordan and The Hashemite University, which are treated as a representative sample of universities of the middle province in Jordan, so that the results would be generalized to the entire province. The researchers frequently visited buildings and toilets randomly selected from different faculties at these universities during the first semester 2016-2017.

\section{Data Analysis and the Theoretical Framework}

Data were qualitatively and quantitatively analysed. The number of graffiti messages was counted. Percentages and frequencies of the graffiti writings were rolled out and tabulated. The inscriptions were recorded by the researchers and were then transcribed for further analysis. Examples of graffiti have been presented in their original form so as to 
help capture and retain the message intended by the graffitist. The language of such inscriptions was analysed at different levels: functional, lexical, and syntactic.

Following the methodology employed in the foregoing related studies for analysing the data (ElNashar, \& Nayef, 2016; Morva, 2016; Stampoulidis, 2016; Yeo, et al., 2016) and that specifically serves the objectives of the present study, thematic analysis (Braun \& Clarke, 2006) and Critical Discourse Analysis (Fairclough, 1995) are considered the main tools for quantitative and qualitative clarification. The Thematic analysis is a flexible qualitative method used to analyse data (i.e. graffiti) by collecting similar thematic codes to pertinent groups of meaning (Braun \& Clarke, 2006). It is appropriate and beneficial when the researcher aims to examine the data in order to determine common themes and thoughts from more than one participant so as to gain a clear logical understanding of the participants' thoughts and experiences (Crawford et al. 2008). Thus, it allows the researchers to associate an analysis of the frequency of a theme with one of the whole content which will in turn confer accurateness and enhance the research's interpretation and whole meaning (Alhojailan, 2012). According to Namey et al. (2008),

Thematic moves beyond counting explicit words or phrases and focuses on identifying and describing both implicit and explicit ideas. Codes developed for ideas or themes are then applied or linked to raw data as summary markers for later analysis, which may include comparing the relative frequencies of themes or topics within a data set, looking for code co-occurrence, or graphically displaying code relationships. (p.138)

In particular, the "raw" data were firstly read and visually scanned many times for distinctive connection and patterns, and then reduced through being classified into meaningful concepts. The resultant concepts were then grouped into relevant overarching categories or themes in order to examine the content and the contextual meanings of the distinctive examples of students' graffiti as demonstrated in Table 1. For example, all the words and expressions taken from the Holy Quran and Hadith were classified under the theme called religious. Afterwards, the resultant themes were revisited and reviewed so as to ensure that the whole data fitted under the formulated themes. Thematic coding allows the researchers to review the whole data by recognizing its most significant meaning or what the data is trying to say or tell (Halldorson, 2009). This method, as Braun \& Clarke (2006, p. 5) claimed can "potentially provide a rich and detailed, yet complex account of data" and patterns and made the examination of the data easier. Braun \& Clarke's thematic analysis of discourse is based on
Fairclough's (1995) Critical Discourse Analysis, as there is an interaction between the text, discursive practices, and the social context (Ngulube, 2015). Therefore, it is valuable and essential to acknowledge the importance of graffiti discourse as a product of human linguistic expression besides the nature and impact of the message being conveyed (Onyango, 2016). Onyango (2016) added that the significance of graffiti discourse should be recognised as a mode of communication informing about main social issues and problems.

The researchers have adopted Fairclough's (1995) Critical Discourse Analysis which adequately accounts for the successful interpretation of graffiti on universities' walls. Fairclough (1995; 2003) argued that analysing a text should take into account various elements: functional, lexical, grammatical, coherence, and textual structure. Fairclough $(1989,1995)$ extended the notion of discourse from a merely unprompted and natural "language in use" (Brown \& Yule, 1983) and a means to recognize the speakers' intentions (Van Dijk, 1985) to be part and product of social practices (Chiluwa, 2008). Fairclough (1995) contended that "ideologies reside in texts" that "it is not possible to 'read off' ideologies from texts" and that "texts are open to diverse interpretations" (p. 71). Critical Discourse Analysis scrutinizes the mutual interplay and relationships between people's texts, events, and practices and broader socio-cultural structures to reflect on the way these texts, events, and practices arise out of and are ideologically shaped by relations of power. This view is pertinent to this study in that it offers an explanatory framework for graffiti writing as an incident that is affected by the social milieu and as one that also influences it. In this study, students are perceived as people employing language to express various types of concerns and communicate difficulties they face in their institutions. Adopting this theoretical framework model, this study investigates graffiti on universities' walls in Jordan as a social practice that is the creation of social practices on both the individual and institutional levels which yield and replicate them so as to preserve their incessant existence (Fairclough, 1995). Thus, graffiti writings provide an explicit image and insightful understanding of the numerous changes being economic, educational, political, social etc. in the society.

\section{RESULTS AND DISCUSSION}

The data yielded a total of 378 graffiti written on universities' walls. The vast majority were ostensibly written on the abovementioned walls as very few (mainly taboos) were written in hidden corners and toilets' walls. This may be driven by the graffitists' intention to allow the viewer to see 
the writings clearly immediately upon entrance to each place.

\section{What communicative functions do graffiti- writings serve?}

The qualitative thematic analysis of the undertones of the collected graffiti shows that they serve various communicative functions which can be classified based on their prevalence/amount under the certain distinct themes. The qualitative analysis of the graffiti obtained with respect to each theme is presented in Table 1.

Comparing the themes expressed via graffiti yields the following results. As pointed out in Table
(1), it is apparent that the highest percentage of these inscriptions, which is $(34 \%)$, is related to the personal themes. Social and national themes are also significant. They constitute $20 \%$ of the overall number of language themes located on the walls. The third frequent theme in the data is related to the graffiti that were classified under the theme of others with a percentage of $18 \%$. Religious themes rank fourth with a percentage of $17 \%$. Political themes are expressed less with the percentage of $7 \%$. The unacceptable expressions (taboos) are, on the other hand, the least frequently occurring theme in the examined corpus with a percentage of $4 \%$.

Table1. The themes expressed in graffiti

\begin{tabular}{cc}
\hline Themes & Percentages \\
\hline Personal & $34 \%$ \\
\hline Social and National & $20 \%$ \\
\hline Others & $18 \%$ \\
\hline Religious & $17 \%$ \\
\hline Political & $7 \%$ \\
\hline Unacceptable expressions(taboos) & $4 \%$ \\
\hline
\end{tabular}

\section{Personal Themes}

The personal expressions are mainly a reference to oneself, family, friends, lecturers, acquaintances, and beloved ones. They are mostly a reflection of mental, physical. or emotional reaction to pleasure, pain, and hatred they or those they know experience throughout their life. For students, the depiction is mainly university life's challenge and happiness. This implies that the personal expressions can be seen as a way of alleviating the pressures and anxieties of university life. Complaint statements are used to reflect their despair and express their resentment. Graffiti present some of the major, student or university oriented matters that mirror controversies that students and campuses must deal with at the time. While some of them poke fun at certain faculties, textbooks, classrooms, lecturers, course subject, others ridicule the institution's educational and administrative management and procedures. Such graffiti can also be seen as a way students use to attract peoples' attention so as to find some solutions to address their concerns.

The personal expressions also hold romanticised connotations. Students have used certain words, statements, sketches of a heart with names on it, besides romance poetry and songs to declare love, arrange romantic dates, reveal feelings, and leave love memoirs. It also appears that Jordanians students are paying a great attention to celebrities and their songs and poetry. The prevalence of graffiti as chunks of lines of some well-known favourite songs and poems may also be attributed to the fact that students have become obsessed with the contemporary songs and poems, especially those performed by superstar singers and poets. It is becoming evident that graffiti endow them with the courage to explicitly profess their love feelings.

Some graffiti are merely expressions of some personal data using names, nicknames, mobile and phone numbers, signatures, marking important dates. There are also statements of academic notelectures in forms of outlines, grammatical rules, or math formulas (e.g. $\mathrm{A} 2+\mathrm{B} 2+1=6-, \mathrm{A} 2+\mathrm{B} 2 / 6$ ) , which are probably written to be used in exam time,

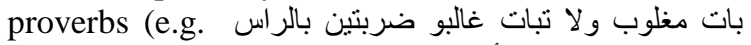

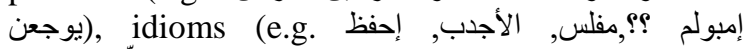

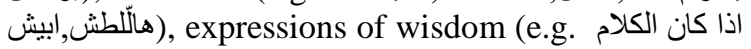

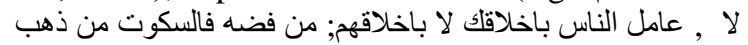
(تبالغ في المجاملة حتى لاتسقط في بئر النفاق abstract words which represent abstract noun (i.e. القوة, power; patience, الصبرand friendship, الصداقة). These sorts of graffiti are students' valuable source of help for improving their learning experiences, thinking capabilities, language skills, and understanding of themselves and the world. They are the knowledge, experience, common sense that help them sharpen their sound judgment abilities and enjoy a peaceful and prosperous life. They are an essential part of their life that provides them with outstanding opportunities to express values and beliefs that are closely related to traditions and social-cultural norms. They may be viewed as a way of giving a chance for the viewers to imagine the intended messages.

Though some of these graffiti are driven by inner personal feelings, such as love, boredom, and anxiety, others are motivated by the intention to show anger towards these messages, add to, or respond to other formerly written graffiti. Table 2 demonstrates some examples of these personal expressions with their translation. 
Table2. Examples of the personal themes expressed in graffiti

\begin{tabular}{|c|c|}
\hline Personal Expressions & Translation \\
\hline انت حبي الاول و الاخير & You are my first and last love \\
\hline تخصصي كثير صعب & My specialisation is very difficult \\
\hline انا بكره الامتحانات & I hate exams \\
\hline حبي تقابلنا على باب دكتور & My love, we met at a doctor's office \\
\hline انا محبط جدا & I am very depressed \\
\hline هم الدهر ياناس حطم شبابي & The life's burden destroyed my life \\
\hline شو اعمل ؟؟؟؟؟؟؟؟؟؟ & What should I do?????????? \\
\hline ز هقت! بدي اتخرج.......... & I want to graduate......I got fed up! \\
\hline افهمني & Understand me \\
\hline تصور شو صعبة المساله & Imagine how difficult this issue is \\
\hline موجوع قلبي & My heart is aching \\
\hline الناس تتكلم و انا اتالم & People are taking and I am suffering from pain \\
\hline حب للابد , يارب تكوني من نصبيب & Love forever, may Allah make my destiny \\
\hline احبك حب ماله حدود & I love you without limits \\
\hline خذ واعطي & Give and take ( let us communicate/discuss ) \\
\hline صديقات عمري مميز ات & My friends are special \\
\hline ابوقديس مبروك التخرج & Abu Gdais, congratulation on your graduation. \\
\hline الابداع هو ان نرى ما لاير اه الناس ونفكر بما لم يفكر به الاخرون & $\begin{array}{c}\text { Creativity is to see what people can't see and think of what } \\
\text { others can't think of }\end{array}$ \\
\hline انا الوم نفسي & I blame myself \\
\hline باليت الزمن برجع & I wish that times goes back \\
\hline ملعون ابو الدر اسه م & Damn on studying \\
\hline الذي قال ان هنالك فرق بين الناس :بعضهم علاج للروح و الاخر الاخر يسبب & $\begin{array}{l}\text { He who said "there is difference between people; some are } \\
\text { a healer to the soul and some cause pain" was honest. }\end{array}$ \\
\hline إل مافي زي جامعتنا & There is nothing like our university \\
\hline
\end{tabular}

\section{Social and National Expressions}

This type of graffiti demonstrates that they can be viewed as an explanation of a wide realm of the societal conduct. They may also be regarded as a creative way of getting their message out there and publicly displaying nationalist ideals. Expressing patriotism is the most notable theme among these types of graffiti. Jordanians are well known for their strong love, attachment, and support to their country and their leadership. They hold a great sense of responsibility towards their motherland. They feel proud of their Jordanian customs, virtues, values, and traditions. They dedicate themselves to their country by setting the interests and welfare of their country above all their personal achievements. Very related to this leitmotif is the second noteworthy theme, which is expressing tribal loyalty. Patriotism denotes allegiance and belonging to their ancestors, homeland, and leadership. Jordan is known as a tribal country. The highest occurrence of such theme may be ascribed to the students' loyalty to their mother country, devotion to their leadership, their tribes and some groups of people. They are greatly proud of Jordanian nationality. Table 3 illustrates some examples of social and national themes expressed in graffiti.

The graffitists also reveal their loyalty to Palestine as it was a part of their country years ago. Their feeling of strong attachment to this sacred place and the holiness of Jerusalem urge them to release their frantic outbursts of emotion through graffiti.

They mostly express their devotion to their sport teams and players, such as football national team (i.e. Al-Faisali and Al-Wihdat). It is very apparent that a great amount of attention is being paid to sport in Jordan. This is because most students, males and females, are fanatical about sport, specifically football. Their obsession with sport helps them express their devotion and solidarity to their homeland. Sport in general is a source for promoting values, thoughts, and beliefs and developing the community members' mental and physical skills as well as a symbol representing their country in world competitions. This patriotic symbol which is well-rooted in Jordanians' souls and minds has reached its zenith in universities. This is due to the fact that universities play a crucial role in promoting a strong interest in sport, as it reflects success and achievement of its students.

\section{Religious Themes}

The religious expressions are demonstrated in different forms. The religious themes encompass references to Allah, Prophet Muhammad (PBUH), the Holy Quran and Hadith, preaching, prayers, and supplications. The vast majority of these expressions are in sort of supplications in which the graffitists seek help, support, and mercy from Allah.

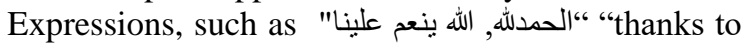
God, may Allah shower us with blessings" are the most common religious expressions found on universities' walls. This can be ascribed to the fact that Jordan is mainly a Muslim community where the large majority (approximately 90\%) of Jordanian people are Muslims. It is worth noting that no occurrences of Christian expressions were spotted on the university walls despite the fact that $10 \%$ of the Jordanians are Christians. 
Table3. Examples of the social and national themes expressed in graffiti

\begin{tabular}{|c|c|}
\hline Social and national themes & $\begin{array}{c}\text { Translation } \\
\end{array}$ \\
\hline بالرو بالدم نفديك يا اردن & By our souls and blood we save Jordan \\
\hline الاردن بالقلب & Jordan in our heart \\
\hline عبدالله ياعونك & Abdullah we are your support \\
\hline الاردن اولا & Jordan First \\
\hline فلسطين عربيه & Palestine is Arabic \\
\hline الفيصلي الزعيم & Al-Faisali is the leader \\
\hline القدس عربية & Jerusalem is Arabic \\
\hline ياناس طفر ان & Oh people, I have nothing (poor) \\
\hline بني حسن وبس & Bani Hassan only (A name of a tribe) \\
\hline بني صخر, افضل الناس & BaniSakhir ( (a tribe's name), the best people ever \\
\hline السلط و اقطع ! & Al-salt and cut (say nothing)! \\
\hline لعل حزن اليوم يصبح غيمة تمطر فرحا غدا & $\begin{array}{l}\text { May today's sadness become a cloud raining happiness } \\
\text { tomorrow }\end{array}$ \\
\hline كركي ياخال & I am Karaki (from Al-Karak), My uncle \\
\hline اردني وارفع ر اسك & Jordanian and lift your head \\
\hline كل عام و انتم بالف خير & happy New Year for you all \\
\hline لوكان الفقر رجلا لقتلته & If the poverty were a man, I would kill him \\
\hline
\end{tabular}

Some of the expressions are a sort of reiteration of faith, either through using Quranic verse citations (both a whole Quranic verse and part of it), such as "Say, $\mathrm{He}$ is Allah, the One", personal faith affirmations in the form of Islamic "Shahada" (i.e. a testimony where a Muslim bears witness that there is no god but Allah and that Muhammad is His Messenger), or Hadith (prophet Muhammad (PBUH) and his companions sayings) such as, "he who says there is no God except Allah will enter Jannah (Paradise)". There are also graffiti which are merely religious words, such as Allah's 99 Names (e.g. The Merciful) and Islamic tenets based-

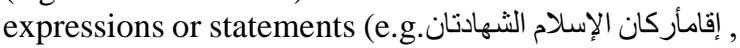
حج البيت خمس:الصلاة, إيتاء الزكاة,صومشهر ,رمضان, The five pillars of Islam; Al-Shahadatan, prayers, Giving Zakat, fasting the Month of Ramadan, the pilgrimage to Makkah). There are also few occurrences of preaching statements (e.g. enjoining what is right, forbidding what is wrong, such as (لاتتكلم على الناس لانك ستأكل لحمهم ميتا (). Table 4 demonstrates some examples of graffiti's religious themes with their translation.

The prevalence of such religious expressions can be ascribed to the fact that Islamic religion is considered as an integral part of Jordanians' entire life, as it plays a noteworthy role in every aspect of their life and is intertwined with many people's beliefs. It is intrinsic in the teachings of the Holy Quran that guiding people to behave well is the duty of every Muslim. This implies that graffiti are vehicles used to convey messages that urge their viewers to follow the acceptable code of conduct. It should be noted that some of these religious expressions reveal some other concerns of the Jordanians, such as intrinsic fear of the supernatural power of envy. Jordanians have a strong belief in the Quran power that can ward off the evil eye. This implies that graffiti can be viewed as a product, reflection, and propagation of the society's ideologies.

\section{Political Expressions}

Some of the graffiti are a mere illustration of students' opinions and attitudes towards various revolutionary and non-revolutionary issues. They are mainly expression of resentment and displeasure, denial and disapproval over political issues. This signifies that students find university surfaces a refuge to express their oppositions to certain national and international policies, rules, and regulations. In other words, these types of graffiti could be perceived as resistance to the existing policies, rules, and regulations and as tributes to revolution. The graffiti are also a reflection of the students' dominating political thoughts of the scourges of war in countries near Jordan and a depiction of their people's suffering (i.e. Palestine, Syria, Lebanon and Libya, and Iraqi crisis). Thus, university walls have become a political arena on which students speak up their views and political comments and approach the political matters without fear.

This finding lends support to Whitford's (1992) finding that graffiti are an effective option used as a medium for the manifestation of political disillusionment or defiance. The finding is also in line with Chaffee's (1990) claim that graffiti-writing is one of the easiest and most effective ways for persons and groups to voice their political nonconformity, social alienation, and anti-system thoughts. Table 5 demonstrates some examples of graffiti's political themes with their translation. 
Table 4. Examples of the religious themes expressed in graffiti

\begin{tabular}{|c|c|}
\hline Religious themes & Translation \\
\hline بسم الله الرحمن الرحيم & $\begin{array}{l}\text { In the name of Allah, the most merciful, the most } \\
\text { gracious }\end{array}$ \\
\hline حسبي الله & Allah is my suffice \\
\hline ربي اوز عني ان اشكرك نعمتك التي انعمت علي وان اعمل صالحا & $\begin{array}{l}\text { "O my Lord! so order me that I may be grateful for Thy } \\
\text { favors and I do something good }\end{array}$ \\
\hline 父 الله الله الله & There is no God except Allah \\
\hline الله جل جلاله & Allah is Exalted and Majestic \\
\hline محمد صلى الله عليه وسلم & Prophet Muhammad Peace Be Upon Him (PBUH) \\
\hline \multicolumn{2}{|l|}{ السلام ,القدوس ,المهيمن } \\
\hline وان محمدا رسول الله الهـ الان & $\begin{array}{c}\text { I bear witness that there is no god but Allah and that } \\
\text { Muhammad is His Messenger }\end{array}$ \\
\hline اللهم احفظنا وارحمناوانت خير الر احمين & $\begin{array}{c}\text { May Allah save us and shower mercy on us. Allah is the } \\
\text { best saver. }\end{array}$ \\
\hline الله المستعان & Allah is my help \\
\hline قل اعوذ برب الفلق....... من شر غاسق اذا وقب & $\begin{array}{l}\text { Say, 'I seek refuge in the lord of the dawn....... And from } \\
\text { the evil of the envier when he envies". }\end{array}$ \\
\hline عبار ات اسلاميه للتذكبر وكسب الاجر : اذكروا الله, صلوا على & $\begin{array}{c}\text { Islamic expressions to remember and to get reward: } \\
\text { mention Allah and pray to the prophet (say Muhammad } \\
\text { peace be upon him) }\end{array}$ \\
\hline خيركم من تعلم القرن و علمه & $\begin{array}{c}\text { "the best amongst you are the ones who learn Qur'an and } \\
\text { teach it to others" }\end{array}$ \\
\hline
\end{tabular}

Table 5. Examples of the political themes expressed in graffiti

\begin{tabular}{|c|c|}
\hline Political themes & Translation \\
\hline حلب تحترق ! & Aleppo is burning! \\
\hline فلسطين تحت الاحتلال & Palestine is under occupation \\
\hline يسقط حكم بشـار & The rule of Bashar will get down \\
\hline ثوره ,ثوره , انتفاضه & Revolution, revolution, intifada \\
\hline قربت الحرب و النهايه & The war and the end are near \\
\hline
\end{tabular}

\section{Unacceptable expressions (i.e. taboos)}

Graffiti expressing taboo words and expressions have been found to be the least frequent occurrence. Al-Sadi and Hamdan (2005) defined taboo as words or expressions that talk about topics people generally avoid, as they are considered shocking, offensive, or embarrassing. Graffiti taboos are impolite words or expressions intended to offend or hurt others. Students use such graffiti to disdain each other with offensive insults about themselves, families, counterparts, and strangers. They are mainly apparent on washrooms' walls, particularly male's. This could be referred to the fact that students can freely and anonymously express their opinions without being witnessed by others. Students seek anonymity so as to avoid being stigmatized by producing such unacceptable expressions. The amount of male students' socially unacceptable expressions and words that outnumber female students' could signify that females show more politeness and respect than do their male counterparts. It is also notable that graffiti functioned as a dialogue between those writing insulting words. In other words, certain graffiti are merely a matter of exchanging insults (e.g. the one who wrote this, I will curse her and I wish the same bad thing even more happen to her). This could be due to students' anger when they find their names associated with an abusive expression. In other words, they feel unable but to reply the insulting messages directed to him/her. Some graffiti constitute a request for friendship, whereas some others constitute revenge from an ex-friend. These are either socially (e.g.أمه عديمه الثرف, a nation without honour, politically (e.g. العرب انذال وخونها Arabs are coward and deceitful) personally (سامي و احد مش مثربى وقليل ادب ، لذب , Sami is not well-brought up and is ill- mannered), or religiously (e.g. يلعن حظي) constructed. It is evident that graffiti with sexual contents are absent in the analysed data for this study. This is mainly because sexuality in such social and academic community is mostly forbidden. Table 6 demonstrates some examples of graffiti's taboo themes with their translation.

The findings match other researchers' (Gross et al., 1997) finding that graffiti constitute an act of self-disclosure and a manifestation of the graffitists' personal nature with sheer privacy and anonymity. They constitute a legal podium for voicing their personal, social, cultural, political rights encompassing particular principles, such as expressing dignity, freedom, equality, and autonomy. They also reflect certain psychological motives that drive graffitists to write, such as depression, oppression, poverty, emotional, and health problems. 
Table 6. Examples of the taboo themes expressed in graffiti

\begin{tabular}{|c|c|}
\hline Taboo themes & Translation \\
\hline مقرفه جدا & You are very disgusting \\
\hline طز عليكو & Damn on you \\
\hline كذابه & You are a liar \\
\hline 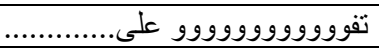 & A spit on .............. \\
\hline ابن حر ام ............ & Son of a bitch \\
\hline بنات شوارع & Street girls \\
\hline غبي, حيو ان, كلب, وحقير & Stupid, animal, dog, despicable \\
\hline واحد كندرةتربيكطز في & Damn on upbringing, you are a shoe \\
\hline طيب انخرس احسنلالك & OK, SHUT UP. That is better for you \\
\hline
\end{tabular}

These inscriptions can be viewed as a human characteristic which implies the graffitists' intrinsic urge and obsession to leave behind a mark on the world to proclaim ones' existence, leave a mark of remembrance, and provide a sense of permanence. A memoir such as “ تحيات المعذب بالحب 2/2015/5 "With regards, the love tortured Samer 5/2015/2" is defined by Zuwiyya (2000) as a piece of autobiographical inscription that is normally shorter than a full autobiography tagged with name and date and tries to depict a contemplation of the meaning of specific significant moments, scenes, or events in people life. However, the less frequent occurrence of such memory graffiti may be ascribed to the fact that good memories not bad ones are mostly recorded and that not all students like to be remembered by others due to those bad memories they experience during their academic journey.

\section{Others}

Under the "others" category is humorous graffiti which are prevalent in the university context. They are mainly expressions written by those who have distinctive sense of funniness and hope to elicit a smile from their graffiti viewers. They are perceived as an invocation of amusement and a vent of their anxiety so as to be much happier, more sociable, and capable of coping with challenges. They are mainly jokes (e.g. رجع وقال ربنا يشافيها ارجع اشوفها لما ترجع),

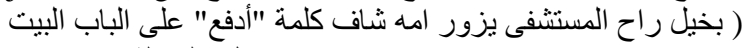

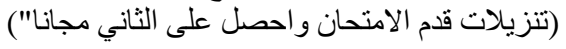

Scribble and drawings graffiti are also classified under the category of "others". They could be ascribed to boredom; what the graffitists feel at that point of time in that place. These may be a result of having nothing but to etch with sharp objects or draw with markers on surfaces. They are either mere scribbling or portrayals of facial expressions (e.g. a smiley face, sad face, tearing eyes, broken hearts with an arrow) ${ }^{\mathrm{i}}$, and body language (e.g. thumb ups) that represent their psychological feeling of certain issue and others (a flower, a book, a lamp, a candle). The broken hearts with an arrow and a name, for example, signify sorrow over the absence or loss of that name. Table 7 illustrates some examples of those themes classified under "others".

Table 7. Examples of the themes classified under other theme in graffiti

\begin{tabular}{c}
\hline $\mathrm{M}+\mathrm{H}$ \\
\hline+$)$ \\
\hline : \\
\hline $\mathrm{A}$ \\
\hline Ghsan $27 / 4 / 2016,9: 58$ \\
MAXX MAHA \\
\hline NB \\
\hline Sultan, the handsome man
\end{tabular}

The huge amount of the graffiti obtained and their underlying themes indicate that students find university walls as their little room for selfexpression. These identity expression texts include names, nicknames, initials, and signatures (intricate curved drawings). The graffito "Mahmoud, English Language and Literature, 20/10/2015 Sig" reveals the identity of its writer who was a student of English language and literature attending a lecture in $20 / 10 / 2015$. The graffitists' signature signifies their authority or presence. The findings show that people enjoy the earnestness to openly write for remembrance which dabbles on people's nature that urges one to want to be reminisced and not be forgotten through time. The findings concur with the finding of Taylor et al. (2010) who asserted that boredom, peer emulation, aggression, identity formation, and retaliations may lead people to be involved in graffiti writing.

In keeping up with the findings of the forgoing studies, the findings of the study lend support to other researchers' findings (Agnes et al., 2014; El- 
Nashar \& Nayef, 2016; Morva, 2016; Onyango, 2016) that graffiti are people's channel to freely and secretly express themselves. The results are in line with many researchers' findings (Farnia, 2014; Dombrowski, 2011; El-Nashar \& Nayef, 2016; Onyango, 2016) that graffiti are different in forms (short words and fragmented sentences) and themes (i.e. conversational, social, religious, and political). The findings are consistent with Farnia's (2014) and Morva's (2016) findings that graffiti act as a reflection of peoples' concern about and understanding of common present-day issues. Moreover, the findings corroborate Pietrosanti's (2010) and Stampoulidis's (2016) results that graffiti mirror the recent uprising and rights movements, political upheavals. This could be ascribed to as Zakareviciute's (2014) claim that graffiti are ostensibly intended as a form of mass communication expected to reach everyone who are physically present at that place.

Overall, it can be concluded that analysing graffiti could be perceived as an extrapolation of students' academic, economic, social and political life. Consequently, it seems that it is valuable and essential to acknowledge and investigate the importance of graffiti as a mode of communication and a representation of human linguistic expression and its underlying message.

\section{What are the distinctive lexical and syntactic features that characterize the language of graffiti-writings?}

The data yielded a total of (378) written graffiti. Graffiti are found to be of a unique and peculiar style of writing; they are found in the forms of text, words, drawings, symbols, and logos that play a prominent role in the discourse. This uniqueness and peculiarity could be ascribed to the medium of communication. In other words, the immensely large space endows the graffitists with an imaginative power that results in such aesthetic pieces mixing image and text.

Language variation is a key characteristic of graffiti on universities' walls. The graffiti are a mixture of both standard Arabic (i.e. Fusha) and vernacular Arabic (i.e. the language used for everyday conversations), a mixture of both Arabic and English (i.e. friendship, complex, leader, welcome, it is too hard to wait), and a combination of the alphabet letters, numerals, and emoticons. Their various forms are intended to effectively communicate meaning. However, Arabic is the most favoured language selected in graffiti texts. Where most of the graffiti are written in vernacular Arabic, standard Arabic is (i.e. Fusha) mainly used in writing verses from the Quran due to its prestigious status as the (language of the Holy Book and everyday prayers). Certain words are spelled differently as "love", "luv", "lv", "4u" 4you" 4y" . It is notable that one word is formed using numerous modes of spelling. The tendency to use loanwords could signify the dominance of some English terms over Arabic ones. They could also be ascribed to the impact of the technological advances and the language devised to be used for SMS texting and communication over social sites.

Most of the graffiti are short content words rather than functional words to communicate ideas, intentions, and feelings as well as to convey loaded messages. For example, "love", "Faisali", "Jordan", "Palestinian", "deprived", "lost". The prevalence of shorts world implies that the reader will lexically broaden them to appropriately interpret their intended meaning.

With regard to sentences, statements are also notable as they enable students to express their thoughts, views, opinions, and other pieces of information. Most of the statements are not typical grammatical expressions. They are mainly fragments described as simple or syntactically less complex and void of punctuation marks. Sentences are written in different forms: statements, dialogues, commands, exclamations, conditionals, and questions. This is because fragments and simple sentences can be easily, hastily, and surreptitiously done so as not to be caught. This could indicate that the graffitists think of their writing as having a complete clear idea, though they are mainly void of clear morpho-syntactic structures. This might also imply that the graffitists think of leaving certain space for the observer or reader of these writing to guess the intended meaning. Some of them employ rhyme specifically when writing some lines of poems or songs. Rhyme is a technique used for its musical impact and to attract readers' attention.

Generally, the findings of this study can significantly contribute to the body of research on discourse studies and sociolinguistics through giving a detailed analysis of language use in society. The present study is also expected to be very valuable to the educational settings as the findings may be interesting not only to university students, but also to a wider audience like educators, administrators, teachers, and parents. They could collaborate, considering the findings to construct a conducive and peaceful learning environment and ultimately improve performance.

Despite its contribution to knowledge, the study has certain limitations which should be acknowledged and addressed in order to pave the way for new fruitful research avenues. These limitations include areas concerning the sample of the study and the inclusion of written graffiti only. The study is limited to two Jordanian universities. Thus, the study can be duplicated to include many other universities in Jordan. Moreover, future research may be conducted, including both the written and the pictorial forms of graffiti. The researchers contend that it is the ramifications of this study for future investigations of graffiti in 
different contexts which are anticipated to prove mainly significant in virtue of verifying or contradicting the existing findings.

\section{CONCLUSION}

The study examines the communicative functions and the linguistics features of graffiti written on universities' walls. The analysis shows that graffiti are used as a distinctive and silent way of communication in the human population, particularly students' society. Graffiti are their ways to voice their feelings, ideas, and attitudes towards certain political, economic, social and personal concerns using their own style reflecting serious student-oriented personal, social, and political issues such as power, intolerance, competition, happiness, and desperation. They can be perceived as a reflection of some underlying ideologies of the Jordanian society and a highly creative, positive medium for people to explore socio-cultural roots, affirm their identities, and promote the ideas they believe in. They mirror and reflect the sediments of dominant beliefs in Jordanian society. All these ideas increase awareness of the importance of graffiti as a hot topic for further investigation. It may be viewed as a good foundation upon which the responsible individuals can rely to improve students' educational, cultural, and social background. There are some other possible avenues for gender-based differences besides stylistic, textual, and semantic features of graffiti-writings at universities, on the seats of public transportation means, and public places. Due to the significant information graffiti may offer, the researchers recommend teachers, educators, and other responsible people pay more attention to students' graffiti writing.

\section{REFERENCES}

Abel, E. \& Buckley, B. (1977). The handwriting on the wall: Toward a sociology and psychology of graffiti. Westport, CT: Greenwood.

Abu-Jaber, H., Yagi, S. M., \& Al-Ghalith, A. (2012). Spelling issues in EFL graffiti: Analysis and implications. European Scientific Journal, 8(21), 56-75.

Adams, K. \& Winter, A. (1997). Gang graffiti as a discourse genre. Journal of Sociolinguistics, 1(3), 337-360.

Agnes, K. Dave, B. \& Waihiga, E. (2014). Graffiti: Communication strategies for secondary school students in Kenya. International Journal of Innovative Research \& Development, 3(1), 184-189.

Al-Khawaldeh, N. (2014). Politeness in the linguistic expression of gratitude in Jordan and England: A comparative cross-cultural study
(Unpublished doctoral dissertation). University of Bedfordshire, England.

Al-Haj Eid, O. (2008). A socio-linguistic study of student graffiti-writings in Unrwa schools, Jordan (Unpublished master's thesis) Philadelphia University, Jordan.

Alhojailan, I. (2012). Thematic analysis: A critical review of its process and evaluation. West East Journal of Social Sciences, 1(1), 39-47.

Al-Sa'di, R. \& Hamdan, J. (2005). Synchronous online chat English: Computer-mediated communication. World Englishes, 24(4), 409424.

Basthomi, Y. (2007). An initial intimation of a yet banal discourse: Truck graffiti. $k @ t a, 9(1), 34-$ 48.

Beck, J. P. (1982). Graffiti: The vulgar blackboard's wit. English Journal, 71(3), 73-74.

Blommaert, J. (2012). The sociolinguistics of globalization. Cambridge: Cambridge University Press.

Blommaert, J. (2016). Meeting of styles and the online infrastructures of graffiti. Applied Linguistics Review, 7(2), 99-115.

Blume, R. (1985). Graffiti. In T. A. van Dijk (Ed.), Discourse and literature: New approaches to the analysis of literary genres (Vol. 3, pp. 137-148). Amsterdam: John Benjamins Publishing.

Braun, V. and Clarke, V. (2006). Using thematic analysis in psychology. Qualitative Research in Psychology, 3(2), 77-101.

Brown, G. \& Yule, G. (1983). Discourse analysis. Cambridge: Cambridge University Press.

Bunting, A. (2012). A sociological study of graffiti in Seville, Spain. Journal of Student Research, 1(2), 51-54.

Chaffee, L. (1990). The popular culture political persuasion in Paraguay: Communication and public art. Studies in Latin American Popular Culture, 9, 127-148.

Chiluwa, I. (2008). Religious vehicle stickers in Nigeria: A discourse of identity, faith and social vision. Discourse \& Communication, 2(4), 371-387.

Crawford, P., Brown, B., \& Majomi, P. (2008). Education as an exit strategy for community mental health nurses: A thematic analysis of narratives. Mental Health Review Journal, 13(3), 8-15.

DeNotto, M. (2014). Street art and graffiti resources for online study. College \& Research Libraries News, 75(4), 208-211.

Divsalar, F., \& Nemati, A. (2012). Social pathology of trust in car written manuscripts. Mediterranean Journal of Social Sciences, 3(3) 363-462.

Dombrowski, Q. (2011). Walls that talk: Thematic variation in University library graffiti. Journal 
of the Chicago Colloquium on Digital

Humanities and Computer Science, 1(3), 1-13.

Dundes, A., (1966). Here I sit: A study of American Latrinalia. Kroeber Anthropological Society

Paper, 34, 91-105.

El-Nashar, M. \& Nayef, H. (2016). Discourse on the go: Thematic analysis of vehicle graffiti on the roads of Egypt. Advances in Language and Literary Studies, 7(5), 227-239.

Fairclough, N. (1989). Language and power. London: Longman.

Fairclough, N. (1995). Media discourse. London: Edward Arnold.

Fairclough, N. (2003). Analysing discourse: Textual analysis for social research. London and New York: Routledge.

Farnia, M. (2014). A thematic analysis of graffiti on the university classroom walls: A case of Iran. International Journal of Applied Linguistics \& English Literature, 3(3), 48-57.

Farnia, M. \& Tohidian, I. (2013). A thematic analysis of truck graffiti in Iranian context. Paper presented at the first national conference on research in teaching English, translation and linguistics (RTELT), 2-3 March, Islamic Azad university of Khorasgan, Iran.

Ferrell, J. (1996). Crimes of style: Urban graffiti and the politics of criminality. Boston: Northeastern University Press.

Gadsby, J. M. (1995). Looking at the writing on the wall: A critical review and taxonomy of graffiti texts (Unpublished master's thesis). Boston, USA.

Grider, S. A. (1975). Con Safos: MexicanAmericans, names and graffiti. The Journal of American Folklore, 88(348), 132-142.

Gröndahl, M. (2012). Revolution graffiti: Street art of the new Egypt. Cairo: American University Cairo Press.

Gross, D. D., Walkosz, B., \& Gross, T. D. (1997). Language boundaries and discourse stability "Tagging" as a form of graffiti spanning international borders. Et Cetra, 54, 275-285.

Halldorson, J. (2009). An exploration of Tajfels social identity theory and its application to understanding Metis as a social identity (Unpublished doctoral dissertation). University of Manitoba, Canada.

Haslam, N. (2012). Psychology in the bathroom. Palgrave: Macmillan.

Hofstede, G. (2005) Culture and organizations: Software of the mind 2nd edition. New York: McGraw-Hill.

House, S. (2007). "Too pretty to do math": The effect of negative, positive, and neutral bumper stickers on math performance in women (Unpublished doctoral dissertation). Chicago University, Chicago.

Kariuki, G., Yieke, F, \& Ndoro, P. (2016). Graffiti on the walls: High school students in Kenya communicating their social issues. Journal of Applied Linguistics and Language Research, 3(6), 160-174.

Karlander, D. (2016). Fleeting graffiti: Backjumps, mobilities and metro semiotics. Tilburg Papers in culture studies, 161, 1-18. Retrieved from http://s3.amazonaws.com/academia.edu.docum ents/43846562/TPCS_161_Karlander.pdf?AW SAccessKeyId=AKIAIWOWYYGZ2Y53UL3 A\&Expires $=1492621243 \&$ Signature $=\mathrm{kgGH} 5 \mathrm{f}$ 5ZV7z2eCk42k5DXVLXPSA\%3D\&responsecontent disposition=inline $\% 3 \mathrm{~B} \% 20$ filename $\% 3 \mathrm{DTPCS}$ _161_Fleeting_graffiti_Backjumps_mob.pdf

Lennon, J. (2014). Assembling a revolution: Graffiti, Cairo and the Arab spring. Cultural Studies Review, 20(1), 237.

Matthews, N., Speers, L., \& Ball, J. (2012). Bathroom banter: Sex, love, and the bathroom wall. Electronic Journal of Human Sexuality, 15(17), 1-11.

McGlynn, P. D. (1972). Graffiti \& slogans: Flushing the Id. Journal of Popular Culture, 2, 351-356.

Mirzaalikhani, S. (2011). Iranian graffiti during political transformation: A semiotic analysis of graffiti before and after revolution (Unpublished doctoral dissertation). Eastern Mediterranean University (EMU), Cyprus.

Morva, O. (2016). The humorous language of street dissent: A discourse analysis on the graffiti of the Gezi Park protests. European Journal of Humour Research, 4(2) 19-34.

Mwangi, F. G. (2012). Graffiti Writing and Its Likely Influence on English Language Learning in Selected Secondary Schools in the Larger Laikipia East District, Laikipia County. (Unpublished doctoral dissertation). Kenyatta University, Kenya.

Namey, E., Guest, G., Thairu, L., \& Johnson, L. (2008). Data reduction techniques for large qualitative data sets. In: Handbook for TeamBased Qualitative Research (pp. 137-161). Maryland: Rowman Altamira.

Ngulube, P. (2015). Qualitative data analysis and interpretation: Systematic search for meaning, in Mathipa, ER \& Gumbo, MT. (eds), Addressing research challenges: making headway for developing researchers (pp. 131156). Noordywk: Mosala-MASEDI Publishers \& Booksellers cc.

Nwoye, O. G. (1993). Social issues on walls: Graffiti in university lavatories. Discourse \& Society, 4, 419-442.

Oganda, O. (2015). The language of graffiti on public transport vehicles in Kenya: Issues and perspectives. International Journal of Education and Research, 3(6), 47-56.

Onyango, O. (2016). The talking walls of Rongo University College: A linguistic analysis of graffiti use at Rongo University College. 
International Journal of Academic Research in Progressive Education and Development, 5(1), 1-6.

Peiris, D. \& Jayantha, K. (2015). A Case Study on Emotion Types of Graffiti Writers in Jogging Paths, Sri Lanka. Journal of Humanities and Social Science, 20(7), 63-67.

Pietrosanti, S. (2010). Behind the tag: A journey with the graffiti writers of European walls. Amsterdam: University of Amsterdam.

Raymonda. (2008). The Sociolinguistics study of graffiti arts used in Surakarta (Unpublished master's thesis). Muhammadiyah University, Surakarta, Indonesia.

Rawlinson, F., \& Farrell, P. (2010). Construction site graffiti: Discourse analysis as a window into construction site culture. In Proceedings of the 26th Annual ARCOM Conference, Leeds, UK (pp. 6-8).

Reisner, R. (1974). Encyclopaedia of graffiti. New York: Macmillan Publishing.

Reisner, R. \& Wechsler, L., (1974). Encyclopedia of graffiti. New York: Galahad Books.

Şad, S., \& Kutlu, M. (2009). A study of graffiti in teacher education. Egitim ArastirmalariEurasian Journal of Educational Research, 36, 39-56.

Salamon, H. (2005). Ha 'am in the turbulent discursive sphere of Israeli bumper stickers. Hebrew Studies, 197-234.

Sheivandi, L., Taghinezhad, A., Alishavandi, A., \& Ranjbar, S. (2015). Exploring linguistic aspects in Iranians' graffiti. Journal of Applied Linguistics and Language Research, 2(5), 6273.

Shohamy, E., \& Gorter, D. (Eds.). (2008). Linguistic landscape: Expanding the scenery. London: Routledge.

Stampoulidis, G. (2016). Rethinking Athens as text: The linguistic context of Athenian graffiti during the crisis. Journal of Language Works, 1(1), 10-23.

Szpila, G. (2012). Regulating the reality? Proverbs in Polish graffiti, Estonia and Poland. Creativity and Tradition in Cultural Communication, 1, 269-284.

\footnotetext{
i Given the limitations of this paper, it should be mentioned that the main focus of this paper is the written rather than the pictorial graffiti. The fleeting reference to the pictorial graffiti in this paper will be further examined in another study.
}

Taylor, M. F., Cordin, R., \& Njiru, J. (2010). A twenty-first century graffiti classification system: a typological tool for prioritizing graffiti removal. Crime Prevention \& Community Safety, 12, 137-155.

Tracy, S. K. (2005). The graffiti method. Australian Midwifery Journal, 18(3), 22-26.

Trahan, A. (2011). Identity and ideology: The dialogic nature of Latrinalia. Internet Journal of Criminology, 1-9.

Vanderveen, G. \& Eijk, G. (2016). Criminal but beautiful: A study on graffiti and the role of value judgments and context in perceiving disorder. Eur J Crim Policy Res, 22,107-125

van Dijk, T. (1985). Handbook of discourse analysis. London: Academic Press.

van Dijk, T. (1999). Critical discourse analysis and conversation analysis. Discourse \& Society, 10(4), 459-460.

Warakomski, J. (1991). The humour of graffiti. In G. Bennett (Ed.), Spoken in Jest (pp. 279-295). Sheffield, England: Sheffield Academic Press Ltd.

Whitford, M. J. (1992).Getting rid of graffiti: A practical guide to graffiti removal and antigraffiti protection. London: E and FN Spon.

Yeo, M., Booke, J. \& Swabey. A. (2016). Shut the F\#\$\%* Up: Forty Years of Student Writing in an Anonymous Forum. Radical Pedagogy, 13(2), 1-19.

Yieke, F. (2003). Graffiti: vandalism or expression academic freedom and intellectualism at universities in Kenya. Paper presented at the conference on Canonical Works and Continuing Innovation in African Arts and Humanities at the University of Ghana in Legon, Accra, September 17-19.

Zakareviciute, I. (2014). Reading revolution on the walls: Cairo graffiti as an emerging public sphere. Hemispheres, 29(4), 5-22.

Zuwiyya, N. (2000). Definitions of memoir. Retrieved from: http:// inkespell. homestead.com/files/Definitions-ofMemoirs.htm. 